\title{
Competitive interactions between corals and turf algae depend on coral colony form
}

Thomas Swierts, Mark JA Vermeij

Turf algae are becoming more abundant on coral reefs worldwide, but their effects on other benthic organisms remain poorly described. To describe the general characteristics of competitive interactions between corals and turf algae, we determined the occurrence and outcomes of coral - turf algal interactions among different coral growth forms (branching, upright, massive, encrusting, plating, and solitary) on a shallow reef in Vietnam. In total, the amount of turf algal interaction, i.e., the proportion of the coral boundary directly bordering turf algae, was quantified for 1276 coral colonies belonging to 27 genera and the putative outcome of each interaction was noted. The amount of turf algal interaction and the outcome of these interactions differed predictably among the six growth forms. Encrusting corals interacted most often with turf algae, but also competed most successfully against turf algae. The opposite was observed for branching corals, which rarely interacted with turf algae and rarely won these competitive interactions. Including all other growth forms, a positive relationship was found between the amount of competitive interactions with neighboring turf algae and the percentage of such interaction won by the coral. This growth form dependent ability to outcompete turf algae was not only observed among coral species, but also among different growth forms in morphologically plastic coral genera (Acropora, Favia, Favites, Montastrea, Montipora, Porites) illustrating the general nature of this relationship. 
1 Short term competitive interactions between corals and turf

2

3

6

8

12 Corresponding author:

13 Thomas Swierts

14 thomas.swierts@naturalis.nl

\footnotetext{
${ }^{1}$ Aquatic Microbiology, Institute for Biodiversity and Ecosystem Dynamics, University of Amsterdam, 1090 GE, Amsterdam, the Netherlands

${ }^{2}$ Marine Biodiversity Past, Present, Future, Naturalis Biodiversity Center, Leiden, the Netherlands

${ }^{3}$ Carmabi Foundation, Willemstad, Curaçao
} 


\section{ABSTRACT}

31 Turf algae are becoming more abundant on coral reefs worldwide, but their effects on other benthic organisms

32 remain poorly described. To describe the general characteristics of competitive interactions between corals and turf

33 algae, we determined the occurrence and outcomes of coral - turf algal interactions among different coral growth

34 forms (branching, upright, massive, encrusting, plating, and solitary) on a shallow reef in Vietnam. In total, the

35 amount of turf algal interaction, i.e., the proportion of the coral boundary directly bordering turf algae, was

36 quantified for 1276 coral colonies belonging to 27 genera and the putative outcome of each interaction was noted.

37 The amount of turf algal interaction and the outcome of these interactions differed predictably among the six growth

38 forms. Encrusting corals interacted most often with turf algae, but also competed most successfully against turf

39 algae. The opposite was observed for branching corals, which rarely interacted with turf algae and rarely won these

40 competitive interactions. Including all other growth forms, a positive relationship was found between the amount of

41 competitive interactions with neighboring turf algae and the percentage of such interaction won by the coral. This

42 growth form dependent ability to outcompete turf algae was not only observed among coral species, but also among

43 different growth forms in morphologically plastic coral genera (Acropora, Favia, Favites, Montastrea, Montipora,

44 Porites) illustrating the general nature of this relationship. 


\section{INTRODUCTION}

56 Benthic algae and corals are among the main groups competing for space on coral reefs (Lang and Chornesky 1990;

57 Karlson 1999; Fong and Paul 2010) and anthropogenic stressors have led to an increase of the former at the cost of 58 the latter (Hughes 1994; Bellwood et al. 2004; Hoegh-Guldberg et al. 2007). Favorable conditions for algal growth

59 are created by the reduced abundance of herbivorous fish due to overfishing and eutrophication resulting from the

60 unsustainable use of coastal areas (e.g., Hughes 1994, Pandolfi et al. 2003, Pandolfi et al. 2005). As algae increase in

61 abundance, they can actively overgrow live corals or passively take over space after corals have died. Feedback

62 processes exacerbate the decline of coral populations as algae provide refuges for coral pathogens and algal exudates

63 fuel bacterial sources of coral mortality (e.g., Kline et al. 2006, Smith et al. 2006, Rohwer et al. 2010).

Many coral reefs have seen large increases in the benthic cover of turf algae, a less noticeable and more complex functional group than the more often studied macroalgae. Turf algae (or "algal turfs") are dense, multi-species assemblages of filamentous benthic algae, including small individuals of macroalgae and cyanobacteria, that are typically less than $1 \mathrm{~cm}$ in height (Connell et al. 2014). The general absence of turf algae in studies of coral reef ecology and conservation is paradoxical because algal turfs are or are becoming one of the most abundant benthic groups typical of degrading reef communities (Littler et al. 2006; Sandin et al. 2008). Compared to other algal groups such as macroalgae and crustose coralline algae (CCA), turf algae occupy available space quicker (DiazPulido and McCook 2002), grow faster (Littler et al. 2006) and are less vulnerable to grazing and water turbulence (Hay 1981; Cheroske et al. 2000). Turf algae can weaken or overgrow and kill neighboring corals, though the particular outcome of a competitive interaction depends on the species involved (Jompa and McCook 2003) and the environmental setting in which the interaction takes place (Vermeij et al. 2010, Barott et al. 2012b).

77 Sessile organisms, like corals, have developed an array of physical and chemical defensive mechanisms against 78 pathogens and predators. These defenses come at a cost since the allocation of resources towards protection reduces those available for growth and reproduction (Herms and Mattson 1992; Endera and Coley 2011; Züst et al. 2011). Reduced growth in response to competitive interaction has been demonstrated in terrestrial plants (Züst et al. 2011)

81 as well as marine sponges (Leong and Pawlik 2010) and the trade-off between fast growth and defense has been a 82 topic of interest in the biology of sessile organisms for decades (Coley et al. 1985, Herms and Mattson 1992, Endara 
83 and Coley 2011). The resource availability hypothesis (RAH), originally proposed for terrestrial plants, can

84 potentially be used for benthic phototrophs and states that the costs of allocating resources away from growth to

85 defenses are relatively higher for fast growers than for slow growers (Endara and Coley, 2011). For slow growing

86 corals, this implies that tissue loss due to predation or competition is more difficult to compensate by regenerative or

87 faster growth, making investing energy in defenses worthwhile. For fast growing corals, the investment in defenses

88 would have a negative effect on growth required to escape competition and therefore these corals may be less

89 inclined to invest energy in defenses.

91 Corals are known for their morphological plasticity and wide variety of growth forms, from encrusting to heavily

92 branched. Branching growth forms are typically fast growing species (e.g. Yap et al. 1992) that extend above the

93 benthos allowing them to avoid interactions with neighboring organisms, including turf algae. In contrast, slow

94 growing and non-erect growth forms (e.g. massive- and encrusting growth forms) are less likely to escape such

95 interactions with neighboring algae. Rather than avoiding competitive interaction through upward growth, such

96 species are expected to actively fight off their opponents (e.g. through the production of secondary metabolites) to

97 survive (Lang and Chornesky 1990; Karlson 1999).

98

99 With the increasing abundance of algal turfs on coral reefs (e.g., Littler et al. 2006; Sandin et al. 2008), it is

100 important to study their interactions with corals and look for general patterns that allow predictions on how coral

101 communities might change in the future. The use of morphological variability in corals as a predictive factor

102 determining the outcome of competitive interactions, i.e., whether a coral wins or loses the interaction, with turf

103 algae could be considered in this context and the usefulness of such approach has already been proven in marine

104 sponges (Bell and Barnes 2003). Following the expectations of the RAH, corals with morphologies associated with

105 fast growth (e.g., branching corals) are less likely to win competitive interactions with turf algae compared to slower

106 growing species that, according to the RAH, would have more resources and/ or mechanisms available to

107 successfully compete with neighboring turf algae.

108

109 In this study we tested for differences among six common coral growth forms (i.e. branching, encrusting, massive,

110 plating, solitary and upright) in terms of the occurrence of turf algal interaction along their edges and their success in 
111 "winning" these interactions. We hypothesized that faster growing species characterized by erect growth forms (i.e.

112 branching, upright) interacted with turf algae along a smaller part of their perimeter compared to slower growing

113 growth forms (i.e. massive, encrusting). Secondly, we hypothesized that growth forms associated with slow growth

114 (i.e. encrusting, massive) would win aforementioned interactions more often than fast growers following the

115 predictions of the RAH.

116

\section{METHODS}

118 Site description This research was carried out in Ninh Van Bay $\left(12.356^{\circ} \mathrm{N} ; 109.277^{\circ} \mathrm{E}\right)$, part of the South Chinese

119 Sea (Fig. 1A) and located nine kilometers northeast of Nha Trang, the seventh largest city of Vietnam. All surveys

120 were conducted between March and April 2013. The reef at our study location extended over approximately 500

121 meter parallel to the wave-sheltered eastern side of Ninh Van Bay between depths of zero and five meters (Fig. 1B).

122 Fishing is prohibited at this site, but occurs in other sections of Ninh Van Bay and adjacent waters (Ngoc et al.

123 2009).

124

125 Benthic cover Photoquadrats were used to quantify the composition of the benthic community (Preskitt et al. 2004).

126 Four transects of 50 meters were deployed with at least 50 meters in between at a depth between two and five

127 meters. Along each transect, 25 quadrats $(0.9 \times 0.6 \mathrm{~m})$ were laid down at $2 \mathrm{~m}$ intervals and subsequently

128 photographed using a digital underwater camera (Nikon AW100 Coolpix). Benthic cover and composition of all

129 major functional groups were analyzed underneath 100 randomly placed points overlain on each picture using Coral

130 Point Count with Excel extensions (Kohler and Gill 2006). Corals and macroalgae were identified to genus-level

131 whereas CCA and turf algae were classified as individual functional groups. Other benthic organisms (e.g., sponges,

132 soft corals) were rare at our study site and not detected in our surveys. Non-biological substrates (e.g. sand, rubble,

133 dead coral) were specified as such.

134

135 Surveys of coral algae interactions To study coral-algal interactions, we used a line intercept approach described

136 by Barott et al. (2009) and Barott et al. (2012b). Along a depth range between two and five meter forty-two transects

$137(25 \mathrm{~m})$ were haphazardly positioned across the reef in various directions so that individual transects never bisected

138 others. Each coral colony on each transect was photographed against a $30 \mathrm{~cm}$ ruler for scale. A top view photo was 
139 taken along with photos from various directions and distances to capture the entire coral-algal boundary. The

140 proportion of coral border involved in each type of coral-algal interaction was later measured in ImageJ 1.48

141 (Abramoff et al. 2004) using the top view photo, whereby side photos and close-ups were used to confirm the initial

142 assessment if necessary. The putative outcome of each interaction was estimated by eye from the same pictures (see

143 below). Algae were classified to genus for macro algae and to a single functional group for turf algae and CCA. The

144 only exception to this method was made for branching Acropora corals since colony bases were generally hidden

145 under an entanglement of branches. These Acropora colonies could exist of more than 100 individual branches. For

146 colonies with more than 40 branches we photographed 40 individual primary branches and used the percentage of

147 branches with algal growth as a proxy for the percentage of the coral border involved in competitive interactions.

148 For smaller colonies, we analyzed all individual primary branches for algal growth. Branches that were completely

149 overgrown from the primary branch upwards were considered dead and not included in the calculations.

150

151 For all colonies interacting with neighboring algae, the putative outcome of each competitive interaction was

152 noted following the classifications of Barott et al. (2012b). In short, competitive outcomes were classified as: (I)

153 coral outcompeted neighboring algae, (II) algae outcompeted neighboring coral, or (III) if there was no obvious

154 "winner" the interaction was classified as neutral. When healthy coral tissue was growing over the algal turfs,

155 corals were assumed to outcompete neighboring algae (see also Figure 2 in Barott et al. (2012b)). Algae were

156 regarded as winning the competitive interaction when the coral colony's edge suffered from bleaching,

157 discoloration, tissue necrosis or when algal turfs overgrew the coral surface. The first two categories are

158 considered 'directional competitive interactions', whereby one organism overgrew or killed its neighbor and

159 eventually would take its place. Note that a single coral colony could be involved in multiple competitive

160 interactions with multiple algal genera or functional groups and that each interaction could have multiple

161 competitive outcomes. Each interaction and their outcomes were included proportionally in our analyses

162 (Supplementary information). We stress that we focused on describing the short-term dynamics of interaction

163 zones and not on the long-term fate of individual colonies. Lastly we measured the maximum coral diameter to

164 investigate a potential relationship between coral colony size and competitive outcome.

165 
166 Definitions of colony growth forms and size classes Every coral colony was classified into one of six growth forms;

167 branching $(B)$, encrusting $(E)$, massive $(M)$, plating $(P)$, solitary $(S)$ and upright $(U)$ (Fig. 2). These classifications are

168 based on commonly used typologies of coral growth forms (e.g., McCook et al. 2001; Muko et al. 2013), that were

169 binned to represent the morphological variation at our study site. Corals showing clear digitate-, corymbose- or

170 branched patterns were grouped as branching (Fig. 2A), whereas all vertical orientated corals lacking these

171 patterns (e.g. columnar- and foliating corals) were classified as upright (Fig. 2B). Massive corals were

172 hemispherically shaped (Fig. 2C). Both plating and encrusting corals grew horizontally, whereby the former were

173 elevated above the benthos and the latter grew over the benthos (Fig. 2D, E). Lastly, solitary corals were non-

174 attached, free-living coral colonies moving over the top of the substratum (Fig. 2F) and in this study only included

175 the genera Fungia and Ctenactis. All colonies were categorized into one of six size classes ('0-5cm', '5-10cm', '10-

176 20cm', ‘20-40cm', '40-80cm', ‘80+cm') following Barrott et al. (2012b). For branching Acropora colonies it was

177 not possible to identify individual colonies in dense Acropora thickets so that this group was excluded from the size

178 class comparisons.

179

180 Statistical analyses We compared the general abundance of algal groups to their relative abundance in coral-algal

181 interactions using a two-tailed binomial test to test whether certain algal groups were over- or underrepresented in

182 coral-algal interactions. Non-parametric, multiple comparisons Kruskal-Wallis tests with Bonferroni corrections (to

183 compensate for multiple comparisons) were used to test for differences in the average proportion of coral edge

184 interacting with turf algae for each of the six growth forms and the six size classes. Non-parametric multiple

185 comparisons Kruskal-Wallis tests were also used to test which different growth forms and different size-classes were

186 more successful in winning competitive interactions with turf algae. For these last tests we used the fraction of

187 corals winning the interaction divided by the total amount of directional competitive interactions (average \% of

188 corals winning / (average $\%$ of corals winning + average $\%$ of algae winning)). Aforementioned tests were not only

189 performed on growth morphology whereby different taxa were binned into one morphological category, but also

190 within morphologically plastic coral genera that harbored multiple growth forms. We only compared growth forms

191 within a single genus, if the growth forms were represented by at least 20 individuals each. Based on this

192 comparison we could detect variation in the performance amongst growth forms without the possibility of falsely 
193 accrediting the differences to genus-specific reactions to turf algae. All statistical analyses were conducted in R (R

194 Development Core Team 2010).

195

196 RESULTS

197 Benthic cover and coral-algal interactions The reef community of Ninh Van Bay was comprised of macro- and 198 turf algae (46.8\%), stony corals (37.5\%) and the remaining 15.7\% consisted of non-biological substrates. The algal 199 community was dominated by turf algae ( $74.6 \%$ of the total algal cover) accounting for $34.9 \%$ of the total reef

200 community. After turf algae, green- (6.5\%; Dictyosphaeria spp.; Halimeda spp. Valonia spp.), brown- (5.0\%;

201 Dictyota spp., Padina spp., Sargassum spp., Turbinaria spp.) and red algae (0.4\%; Amphiroa sp., crustose coralline

202 algae) were the most dominant algal taxa respectively (Table 1).

203

204 The circumferences of the 1046 measurable coral colonies (i.e. all coral colonies except Acropora with a branching 205 growth form) added up to $50538 \mathrm{~cm}$, of which $24049 \mathrm{~cm}(47.6 \%)$ was in direct contact with algae. Again, turf algae

206 were the dominant algal group, accounting for $87.6 \%$ of the total algal community along these coral borders. In the

207 230 branching Acropora coral colonies an estimated $47.0 \%$ of all branches were interacting with algae, of which $91.2 \%$ were algal turfs.

209

210 Coral growth form and coral-algal interactions Of the six growth forms, encrusting corals were most commonly

211 engaged in competitive interactions with turf algae (along 79.3\% of their edges; Fig 3A). In terms of the occurrence 212 of competitive interactions, encrusting corals were followed by massive- (59.1\%), upright- $(49.7 \%)$ and branching 213 corals (27.3\%). Plating- (12.0\%) and solitary corals (12.4\%) experienced the least amount of turf algal interaction of 214 the six growth forms (Fig. 3). Encrusting corals always had more turf algae growing along their borders than all 215 other growth forms, i.e., from 1.34 times more than massive corals up to 6.61 times more than plating corals.

216 Massive and upright coral colonies have more competitive interactions with turf algae than branching, plating and 217 solitary growth forms (Table 2). Only in a few occasions did different morphologies experience a similar amount of 218 coral-algal competitive interaction, i.e., branching and solitary, plating and solitary and upright and massive colonies 219 (Table 2). 
221 The effect of coral growth form on competitive outcomes Similar to above, a colony's success in outcompeting

222 neighboring turf algae depended on its growth form. Encrusting corals were the most successful competitors against

223 turf algae and won 35\% of the interactions (Fig. 3B), followed by plating- (17\%), massive- (13\%), upright- (5\%)

224 and branching corals (2\%). Solitary corals were only observed in neutral interactions or being outcompeted by turf

225 algae (Fig. 3B). Turf algae were least successful in winning competitive interactions with encrusting corals (35\%)

226 and were increasingly better at outcompeting neighboring corals for solitary- (36\%), massive- (38\%), upright-

227 (47\%), plating- (66\%), and branching growth forms (82\%) (Fig. 3B).

228

229 Overall, turf algae won competitive interactions with corals more often than vice versa (Fig. 4), but growth forms

230 that experienced more competitive interactions with turf algae were also more likely to be successful during such

231 interactions. To illustrate, encrusting corals experienced the highest average amount of turf algal interaction along

232 their perimeter, but they were the most successful growth form competing against turf algae, winning $49 \%$ of all

233 competitive interactions (Fig. 4). The opposite pattern was observed for branching corals that had a relatively low

234 number of their branches partly covered by turf algae, but could only be qualified as winning in $3 \%$ of all

235 competitive interactions.

236

237 Taxon or growth form as the main driver of competitive success? For six coral genera (Acropora, Favia,

238 Favites, Montastrea, Montipora and Porites) at least twenty individuals of more than one growth form could be

239 found. Comparing coral-turf algal interactions among growth forms within individual genera again showed

240 differences in competitive outcomes among growth forms within the same genus (Fig. 5). Acropora was the most

241 abundant coral genus on the reef (79\% of total coral cover) and branching corals in this genus experienced three

242 times more competitive interactions with turf algae along there edges than plating Acropora's (Fig. 5A). Corals of

243 the genus Favia were found as massive- and encrusting growth forms that experienced similar amounts of

244 interaction with algal turfs. However, encrusting Favia colonies successfully outcompeted algal turfs more than

245 twice as often as massive colonies (19.8\% vs. 9.6\% respectively) (Fig. 5B). Massive coral colonies within the genera

246 Favites and Montastrea experienced $42.9 \%$ and $33.3 \%$ more interactions with turf algae respectively than encrusting

247 colonies in the same genus (Fig. 5C, Fig. 5D). Within the genus Montipora, encrusting colonies had on average 2.45

248 times more interactions with turf algae along their edges than branching colonies. However, the former outcompeted 
249 turf algae more often than the latter, winning $70.2 \%$ and losing $16.8 \%$ of the competitive interactions whereas the

250 branching colonies were never observed winning an interaction and losing $86.8 \%$ of them (Fig. 5E). Porites was the

251 most variable genus in terms of growth forms. Of the four growth forms we observed, encrusting colonies again

252 experienced more competitive interaction along their borders (76.1\%) than the other three growth forms and

253 branching corals experienced the least (21.4\%) relative to upright- (39.2\%) and massive colonies 47.5\%) (Fig. 5F).

254 Encrusting corals again performed better in these interactions, winning 4.8 times more often than massive colonies 255 and up to 55 times more often compared to branching colonies (Fig. 5F).

256

257 Quantification and outcome of coral-algal interactions per coral colony size class The relative percentage of a 258 colony's border involved in competitive interactions with neighboring turf algae decreased as colonies increased in 259 size (Table 3; Fig. 6A). Colonies larger than $80 \mathrm{~cm}$ experienced 7.5 times less competitive interactions with turf 260 algae along their borders compared to the two smallest size classes (Fig. 6A). However, such differences could not 261 be statistically supported, suggesting that growth form is foremost important in determining the outcome of 262 competitive interactions with neighboring turf algae at our study site (Fig. 6B, C; Table 3).

\section{DISCUSSION}

265 The amount and outcome of competitive interactions between corals and turf algae varied among coral growth

266 forms. Encrusting corals experienced the highest amount of turf algal interaction along their perimeter compared to 267 the other coral growth forms, but they were also more successful in competing against algal turfs. The opposite was 268 observed for branching corals. While branching corals had a relatively low number branches covered with turf algae, 269 they rarely won competitive interactions with turf algae. The other growth forms ranked in between encrusting and 270 branching corals, and growth forms experiencing more competitive interaction from turf algae appeared better able 271 to successfully compete with these turf algae. The fact that similar results were found among and within coral 272 genera, shows that these differences should not only be attributed to genus-specific responses to algal interactions 273 but to growth form specific benefits involved in coral-turf algal competitive interactions.

275 Corals can cope with turf algal competitive interactions in two different ways. First, corals can use an 'escape in 276 height' strategy (Meesters et al. 1996) establishing a relatively small 'perimeter to surface area'- ratio which 
277 minimizes their exposure to nearby benthic competitors. For example, plating corals have flat surfaces but grow

278 slightly above or over the bottom, thereby escaping interaction along the plate's growing edge. The base at which

279 the coral is attached to the benthos is heavily shaded by this plate, which drastically decreases the abundance of light

280 dependent turf algae. When algal turfs do manage to reach the 'plate' of a colony, similar to the branches of

281 branching corals, affected colonies are very likely to lose this competitive interaction. Under the second strategy,

282 corals do not invest energy in vertical growth to avoid competitive interaction with turf algae altogether, but actively

283 fight off algae (McCook et al. 2001) through abrasion, stinging, allelopathy and mucus secretion (Schoener et al.

284 1983; Lang and Chornesky 1990; Karlson 1999).

285

286 Corals in this study appear capable of either quick growth to avoid benthic interaction (e.g., plating and branching

287 colonies) or slow growth in combination with defensive mechanisms (e.g., encrusting and massive species). This

288 apparent trade-off between growth and investment in defenses has many similarities with the resource availability

289 hypothesis (RAH), which states that fast growing, short-lived plant species invest less in defenses compared to slow

290 growing long-lived species, since the relative costs of allocating resources away from growth to defensive

291 mechanisms are higher for fast growing than for slow growing species (Endara and Coley, 2011). Our results

292 strongly suggest that growth forms associated with fast growth (i.e. branching corals) are indeed less successful in

293 competing with turf algae than growth forms associated with slow growth (i.e. encrusting-, massive corals).

294 Ensuring that slow growing species indeed rely on active defense mechanisms to overtake or defend already

295 occupied space within a reef community would be the next step to confirm the applicability of the RAH to corals

296 (e.g., presence of sweeper tentacles, secondary metabolites). Furthermore, our findings were derived from

297 Vietnamese reef communities and should be repeated for other regions before one can generalize our findings on the

298 effects of coral growth forms on the outcome of competitive interactions with neighboring turf algae.

299

300 Shifts in community structure whereby certain growth forms survive stressful conditions better than others have

301 been observed in Japan and resulted in a higher relative abundance of massive- and encrusting corals (Loya et al.

302 2001), confirming expectations following from our findings. The fact that a coral colony's performance in

303 competitive interaction with algal turfs partially depends on its growth form implies that the composition and

304 structural complexity of coral reefs is also likely to change in response to the observed increased presence of turf 
305 algae on reefs worldwide (Gorgula and Connel 2004; Hoegh-Guldberg et al. 2007; Hughes et al. 2007). Acropora is

306 a dominant Indo-Pacific coral genus (Done 1982; Connell et al. 2004), and also the most abundant on our study site.

307 Acropora's have high susceptibility to bleaching (Loya et al. 2001; Marschall and Baird 2000) and breakage during

308 storms (Muko et al. 2013), which, in combination with their suboptimal performance while competiting with turf

309 algae (this study) makes branching Acropora corals especially vulnerable to this seemingly large variety of external

310 stressors. A decrease in the abundance of branching corals would lead to a reduced three-dimensional structure of

311 the reef, with far-reaching effects for other reef organisms, for example fishes, that depend on the shelter provided

312 by the complex structures typical of branching corals (Lirman 1999).

313

314 Our results only partially supported the conclusions from a similar study conducted by Barott et al. (2012b) who

315 found that small- and large-sized corals are better capable in fighting off algae than medium-sized corals. The

316 authors suggested that small corals do not need to invest energy in reproduction, whereas medium sized coral do,

317 and that large corals eventually benefit from the 'escape in height' strategy to avoid algal interaction. Our results

318 indicated that with increasing coral colony size, the percentage of competitive interaction a colony experiences

319 along its border tended to decrease, but no significant relationship could be found. Our findings therefore do not

320 unequivocally support that large corals are better competitors against algal turfs, and suggest that they simply appear

321 to be better in avoiding competitive interaction altogether.

322

323 This study contributes to our understanding of the relationships between coral growth forms and their competitive

324 interaction with turf algae. General patterns were found that transcend species identity which could help understand

325 or quantify biological processes on highly biodiverse coral reef communities in the Indo-Pacific. Coral colony form,

326 rather than size, proved a strong determinant to predict the outcome of competitive interaction between corals and

327 neighboring turf algae.

328

329

330 ACKNOWLEDGEMENTS

331 Many thanks to Six Senses resorts and the entire staff of Ninh Van Bay. Gary Hendon and Joana Sandkühler, thank

332 you for providing all necessities to fulfill the field work and we admire your commitment to this research. 
333 Gratefulness is justified to Selma Ubels for helping with experimental design and sampling. The many discussions

334

335

336

337

338

339

and support are well appreciated. Maarten van Gemert and Friso Dekker provided valuable advice during the analyses. Lastly, we thank Petra Visser for the feedback throughout all stages of the study.

\section{REFERENCES}

Abramoff MD, Magalhaes PJ, Ram SJ (2004). Image Processing with ImageJ. Biophotonics International, volume 11, issue 7, pp. 36-42.

Barott K, Smith J, Dinsdale EA, Hatay M, Sandin S, Rohwer F (2009). Hyperspectral and physiological analyses of coral-algal interactions. PLOS ONE 4: e8043

Barott KL, Rodriguez-Mueller B, Youle M, Marhaver KL, Vermeij MJA, Smith JE, Rohwer FL (2012a). Microbial to reef scale interactions between the reef-building coral Montastraea annularis and benthic algae. Proc R Soc Lond B Biol Sci 279: 1655-1664

Barott KL, Williams GJ, Vermeij MJA, Harris J, Smith JE, Rohwer FL \& Sandin SA (2012b). Natural history of coral-algae competition across a gradient of human activity in the Line Islands. Mar Ecol Prog Ser 460:1-12.

Barott KL, Rohwer FL (2012). Unseen players shape benthic competition on coral reefs. Trends in Microbiology 20: 621-628. doi: 10.1016/j.tim.2012.08.004

Bell JJ, Barnes DKA (2003). The importance of competitor identity, morphology and ranking methodology to outcomes in interference competition between sponges. Marine Biology 143: 415-426.

Bellwood DR, Hughes TP, Folke C, Nyström M (2004). Confronting the coral reef crisis. Nature 429:827-833.

Chadwick NE (1998). Competition and locomotion in a free-living fungiid coral. Jour Exp Mar Biol Ecol 123: 189-200.

Chadwick NE, Morrow KM (2011). Competition among sessile organisms on coral reefs. In: Dubinsky Z, Stambler N (eds) Coral reefs: an ecosystem in transition. Springer Netherlands, Dordrecht, p 347-371.

Cheroske AG, Williams SL, Carpenter RC (2000). Effects of physical and biological disturbances on algal turfs in Kaneohe Bay, Hawaii. $J$ Exp Mar Biol Ecol 248: 1-34.

Connell JH, Hughes TP, Wallace CC (1997). A 30-years study of coral abundance, recruitment, and disturbance at several scales in space and time. Ecol. Monogr. 67, 461-488.

Connell SD, Foster MS, Airoldi L (2014). What are algal turfs? Towards a better description of turfs. Mar Ecol Prog Ser 495: 299-307.

Diaz-Pulido G, McCook JL (2002). The fate of bleached corals: patterns and dynamics of algal recruitment. Mar Ecol Prog Ser 232: 115-128.

Done TJ (1992). Phase-shifts in coral-reef communities and their ecological significance. Hydrobiologia. 247, 121-132.

Fong P, Paul JV (2010). Coral reef algae: the good, the bad, and the ugly. In: Dubinsky Z, Stambler N (eds) Coral reefs: an ecosystem in transition Springer, Dordrecht.

Foster AB (1980). Environmental variation in morphology within the Caribbean reef corals Montastrea annularis and Siderastrea siderea. Bull Mar Sci 30:678-709.

Foster AB (1983). The relationship between corallite morphology and colony shape in some massive reef-corals. Coral Reefs 2:1925.

Gorgula SK, Connell SD (2004). Expansive covers of turf-forming algae on human-dominated coast: the relative effects of increasing nutrient and sediment loads. Marine Biology 145.3: 613-619.

Harvell CD, Mitchell CE, Ward JR, Altizer S, Dobson AP, Ostfeld RS, Samuel MD (2002). Climate warming and disease risks for terrestrial and marine biota. Science 296, 2158-2162.

Hay ME (1981). The functional morphology of turf- forming seaweeds: persistence in stressful marine habitats. Ecology 62: 739-750.

Helmuth BST, Sebens KP, Daniel TL (1997). Morphological variation in coral aggregations: branch spacing and mass flux to coral tissues. $J$ Exp Mar Biol Ecol 209:233-59. 
Heyward AJ, Negri AP (1999). Natural inducers for coral larval metamorphosis. Coral Reefs 18: 273-279.

Hoegh-Guldberg O, Mumby PJ, Hooten AJ, Steneck RS, Greenfield P, Gomez E, Harvell CD, Sale PF, Edwards AJ, Caldeira K, Knowlton N, Eakin CM, Iglesias-Prieto R, Muthiga N, Bradbury RH, Dubi A, Hatziolos ME (2007). Coral reefs under rapid climate change and ocean acidification. Science 318.5857: 1737-1742.

Hughes TP (1994). Catastrophes, phase shifts, and large-scale degradation of a Caribbean coral reef. Science 265: 1547-1551.

Hughes TP, Rodrigues MJ, Bellwood DR, Ceccarelli D, Hoegh-Guldberg O, McCook L, Moltschaniwskyj N, Pratchett MS, Steneck RS, Willis B (2007). Phase shifts, herbivory, and the resilience of coral reefs to climate change. Current Biology 17.4: 360-365.

Jackson JBC, Kirby MX, Berger WH, Bjorndal KA, Botsford LW, Bourque BJ, Bradbury RH, Cooke R, Erlandson J, Estes JA, Hughes TP, Kidwell S, Lange CB, Lenihan HS, Pandolfi JM, Peterson CH, Steneck RS, Tegner MJ, Warner RR (2001). Historical overfishing and the recent collapse of coastal ecosystems. Science 293, 629-638.

Jompa J, McCook LJ (2003). Coral-algal competition: macroalgae with different properties have different effects on corals. Mar Ecol Prog Ser 258:87-95

Jones RJ, Hoegh-Guldberg O, Larkum AWD, Schreiber U (1998). Temperature-induced bleaching of corals begins with impairment of the CO2 fixation mechanism in zooxanthellae. Plant, Cell Environ., 21, 1219-1230.

Karlson RH (1999). Dynamics of coral communities. Kluwer, Dordrecht.

Keats DW, Chamberlain YM, Baba M (1997). Pneophyllum conicum (Dawson) comb nov. (Rhodophyta, Corallinaceae), a widespread IndoPacific non-geniculate coralline algae that overgrows and kills live coral. Bot Mar 40: 263-279.

Knowlton N (1992). Thresholds and multiple stable states in coral reef community dynamics. Am. Zool. 32, 674-682.

Kohler KE, SM Gill (2006). Coral Point Count with Excel extensions (CPCe): A Visual Basic program for the determination of coral and substrate coverage using random point count methodology. Computers and Geosciences, Vol. 32, No. 9, pp. 1259-1269.

Kuffner IB, Walters, LJ, Becerro MA, Paul VJ, Ritson-Williams R, Beach KS (2006). Inhibition of coral recruitment by macroalgae and cyanobacteria. Mar Ecol Prog Ser, 323, 107-117.

Lang JC, Chornesky EA (1990). Competition between scleractinian reef corals: a review of mechanisms and effects. In: Dubinsky Z (ed) Ecosystems of the world, 25. Coral Reefs. Elsevier Science, Amsterdam, p 209-252.

Lirman D (1999).Reef fish communities associated with Acropora palmata: relationships to benthic attributes. Bull Mar Sci 65.1: 235-252.

Littler MM, Littler DS, Brooks BL (2006). Harmful algae on tropical coral reefs: Bottom-up eutrophication and top-down herbivory. Harmful Algae 5: 565-585.

Loya Y, Sakai K, Yamazato K, Nakano Y, Sambali H, van Woesik R (2001). Coral bleaching: The winners and losers. Ecol. Lett. 4, $122-131$. Marshall PA, Baird AH (2000). Bleaching of corals on the Great Barrier Reef: differential susceptibilities among taxa. Coral Reefs, 19, $155-163$.

McCook LJ (1999). Macroalgae, nutrients and phase shifts on coral reefs: scientific issues and management consequences for the Great Barrier Reef. Coral Reefs 18: 357-367.

McCook LJ, Jompa J, Diaz-Pulido G (2001). Competition between corals and algae on coral reefs: a review of evidence and mechanisms. Coral Reefs 19.4: 400-417.

McCulloch M, Fallon S, Wyndham T, Hendy E, Lough J, Barnes D (2003). Coral record of increased sediment flux to the inner Great Barrier Reef since European settlement. Nature 421, 727-730.

Meesters EH, Wesseling I, Bak RPM (1996). Partial mortality in three species of reef-building corals and the relation with colony morphology. Bull Mar Sci 58: 838-852.

Morrow KM, Carpenter RC (2008). Macroalgal morphology mediates particle capture by the corallimorpharian Corynactis californica. Mar Ecol Prog Ser 155:273-280.

Muko S, Arakaki S, Nagao M, Sakai K (2013). Growth form-dependent response to physical disturbance and thermal stress in Acropora corals. Coral Reefs, 32, 269-280.

Namashiro H, Nishihira M (2005). Phototaxis in Fungiidae corals (Scleractinia). Mar Biol 124:461-465. 
Ngoc QTK, Flaaten O, Anh NK (2009). Efficiency of Fishing Vessels Affected by a Marine Protected Area-The Case of Small-Scale Trawlers and the Marine Protected Area in Nha Trang Bay, Vietnam. Integrated Coastal Zone Management, 189-206.

Pandolfi JM, Bradbury RH, Sala E, Hughes TP, Bjorndal KA, Cooke RG, McArdle D, McClenachan L, Newman MJ, Paredes G, Warner RR, Jackson JBC (2003). Global trajectories of the longterm decline of coral reef ecosystems. Science 301, 955-958.

Patterson MR (1992). A mass-transfer explanation of metabolic scaling relations in some aquatic invertebrates and algae. Science, 255, 14211423.

Preskitt LB, Vroom PS, Smith CM (2004). A rapid ecological assessment (REA) quantitative survey method for benthic algae using photoquadrats with scuba. Pac Sci 58:201-209.

Price N (2010). Habitat selection, facilitation, and biotic settlement cues affect distribution and performance of coral recruits in French Polynesia. Oecologia 163: 747-758.

R Development Core Team (2010). R: a language and environment for statistical computing. R Foundation for Statistical Computing, Vienna.

Rasband WS, ImageJ, U. S. National Institutes of Health, Bethesda, Maryland, USA, http://imagej.nih.gov/ij/, 1997-2014.

Rinkevich B, Sakai K (2001). Interspecific interactions among species of the genus Porites from Okinawa, Japan. Zoology 104:91-97.

Sandin SA, Smith JE, DeMartini EE, Dinsdale EA, Donner SD, Friedlander AM, Konotchick T, Malay M, Maragos JE, Obura D, Pantos O, Paulay G, Richie M, Rohwer F, Schroeder RE, Walsh S, Jackson JBC, Knowlton N, Sala E (2008). Baselines and Degradation of Coral Reefs in the Northern Line Islands. PLOS ONE 3: e1548:

Scheffer M, Carpenter S, Foley JA, Folke C, Walker B (2001). Catastrophic shifts in ecosystems. Nature 413, 591-596.

Schoener TW (1983). Field experiments on interspecific competition. Am Nat 122: 240-285.

Smith JE, Shaw M, Edwards RA, Obura D, Pantos O, Sala E, Sandin SA, Smriga S, Hatay M, Rohwer FL (2006). Indirect effects of algae on coral: Algae-mediated, microbe-induced coral mortality. Ecol. Lett. 9, 835-845.

Todd PA (2008). Morphological plasticity in scleractinian corals. Biol Rev 83:315-337.

Vermeij MJA, Sandin SA, Samhouri JF (2007). Local habitat distribution determines the relative frequency and interbreeding potential for two Caribbean coral morphospecies. Evol Ecol 21:27-47.

Vermeij MJA, Smith JE, Smith CM, Vega Thurber R, Sandin SA (2009). Survival and settlement success of coral planulae: independent and synergistic effects of macroalgae and microbes. Oecologia 159:325-336.

Vermeij MJA, van Moorselaar I, Engelhard S, Hörnlein C, Vonk SM, Visser PM (2010). The effects of nutrient enrichment and herbivore abundance on the ability of turf algae to overgrow coral in the Caribbean. PLOS ONE 5:e14312.

Vermeij MJA, Dailer ML, Smith CM (2011). Crustose coralline algae can suppress macroalgal growth and recruitment on Hawaiian coral reefs. Mar Ecol Prog Ser 422:1-7.

Wilkinson C, ed. (2004). Status of Coral Reefs of the World. Townsville, Australia: Australian Institute of Marine Science.

Williams ID, Polunin NVC, Hendrick VJ (2001). Limits to grazing by herbivorous fishes and the impact of low coral cover on macroalgal abundance on a coral reef in Belize. Mar Ecol Prog Ser 222:187-196.

Williams DM, Roth CH, Reichelt R, Ridd P, Rayment GE, Larcombe P, Furnas M, Fabricius K, McCook L, Hughes TP, Hoegh-Guldberg O, Done T (2002). The current level of scientific understanding on impacts of terrestrial run-off on the Great Barrier Reef World Heritage Area. CRC Reef Research Centre, Townsville, Australia.

Yap HT, Alino PM, Gomez ED (1992). Trends in growth and mortality of three coral species (Anthozoa: Scleractinia), including effects of transplantation. Mar Ecol Prog Ser 83:91-1. 
1

Maps of Nha Trang, Ninh Van Bay and study site.

A: The study site is indicated by the red marker $\left(12.356^{\circ} \mathrm{N} ; 109.277^{\circ} \mathrm{E}\right)$. B: All surveys were conducted on the wave-sheltered southeastern side of the reef marked by the white lines. (Map credit: Google, DigitalGlobe)

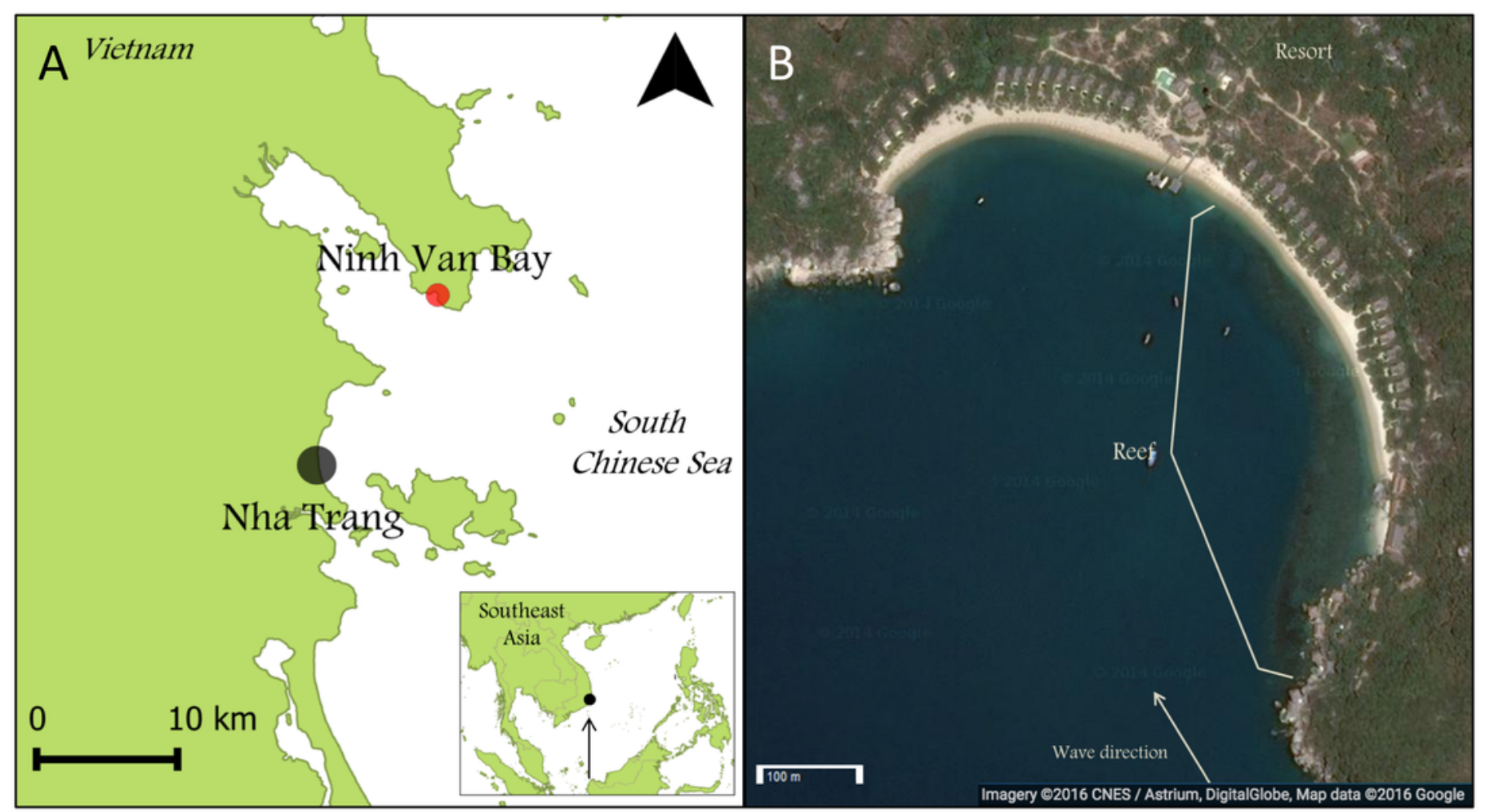


2

Images of classified growth forms.

A: Branching Growth Forms (most dominant genera: Acropora $n=234$, Porites $n=76$, Pocillopora n=66); B: Upright Growth Forms (Porites $n=39$, Pavona $n=36$ ); C: Massive Growth Forms (Porites $\mathrm{n}=98$, Favia $\mathrm{n}=54$, Favites $\mathrm{n}=31$ ); D: Encrusting Growth Forms (Galaxea $\mathrm{n}=57$, Porites $\mathrm{n}=53$, Montipora $\mathrm{n}=48$ ); E: Plating Growth Forms (Acropora $\mathrm{n}=70$, Montastrea $n=6$ ); F: Solitary Growth Forms (Fungia $n=69$, Ctenactis $n=11$ ). All photos are taken by Thomas Swierts. 


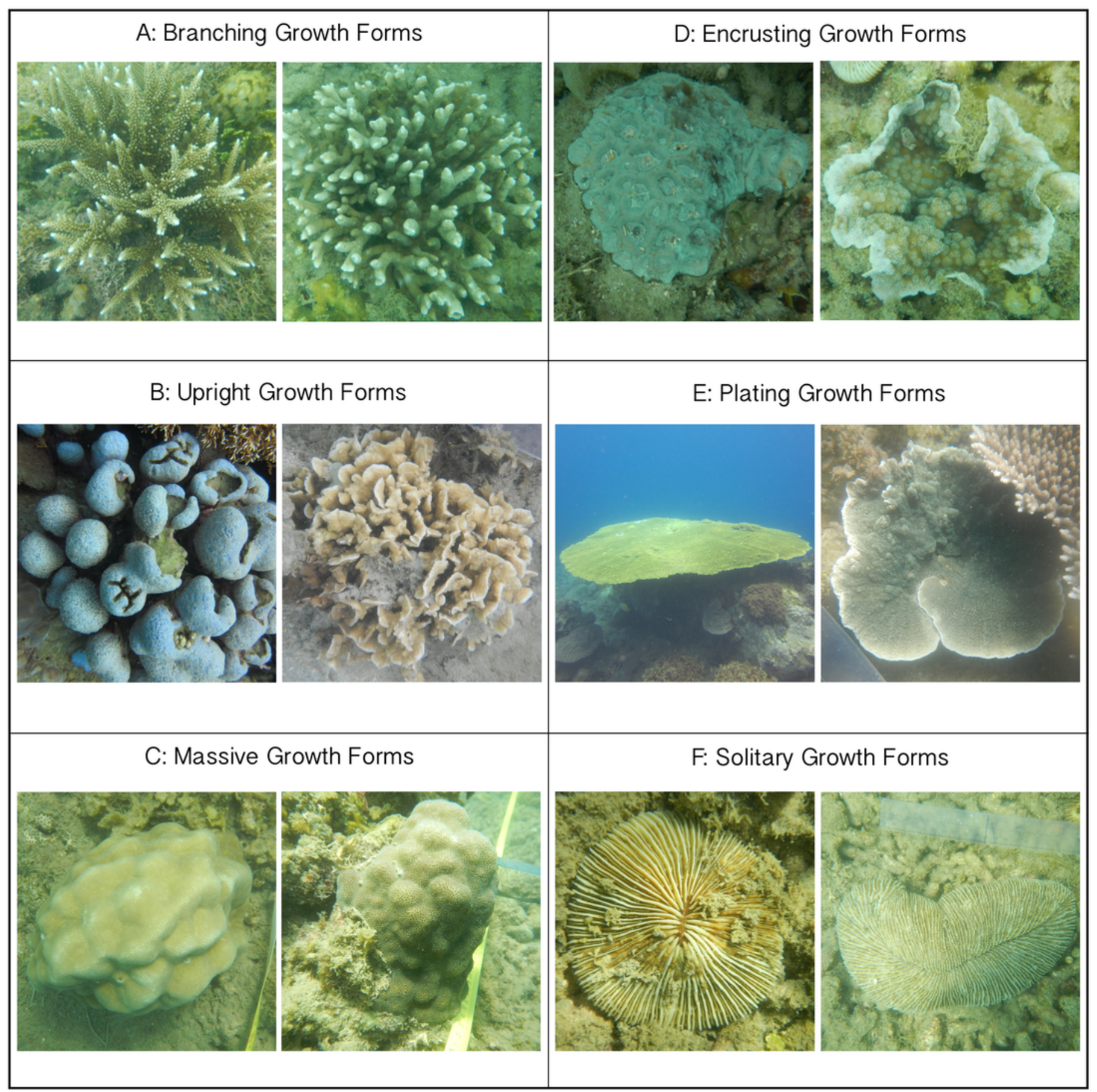


3

Competitive interactions between corals and algae per coral colony growth form.

A: Amount (\%) of coral colony border interacting with turf algae per coral colony growth form. Error bars indicate standard error; numbers indicate the amount of samples. B: Competitive outcomes per coral colony growth form. Purple indicates the proportion of corals winning, orange indicates the proportion of neutral interactions and green indicates the proportion of algae winning. 


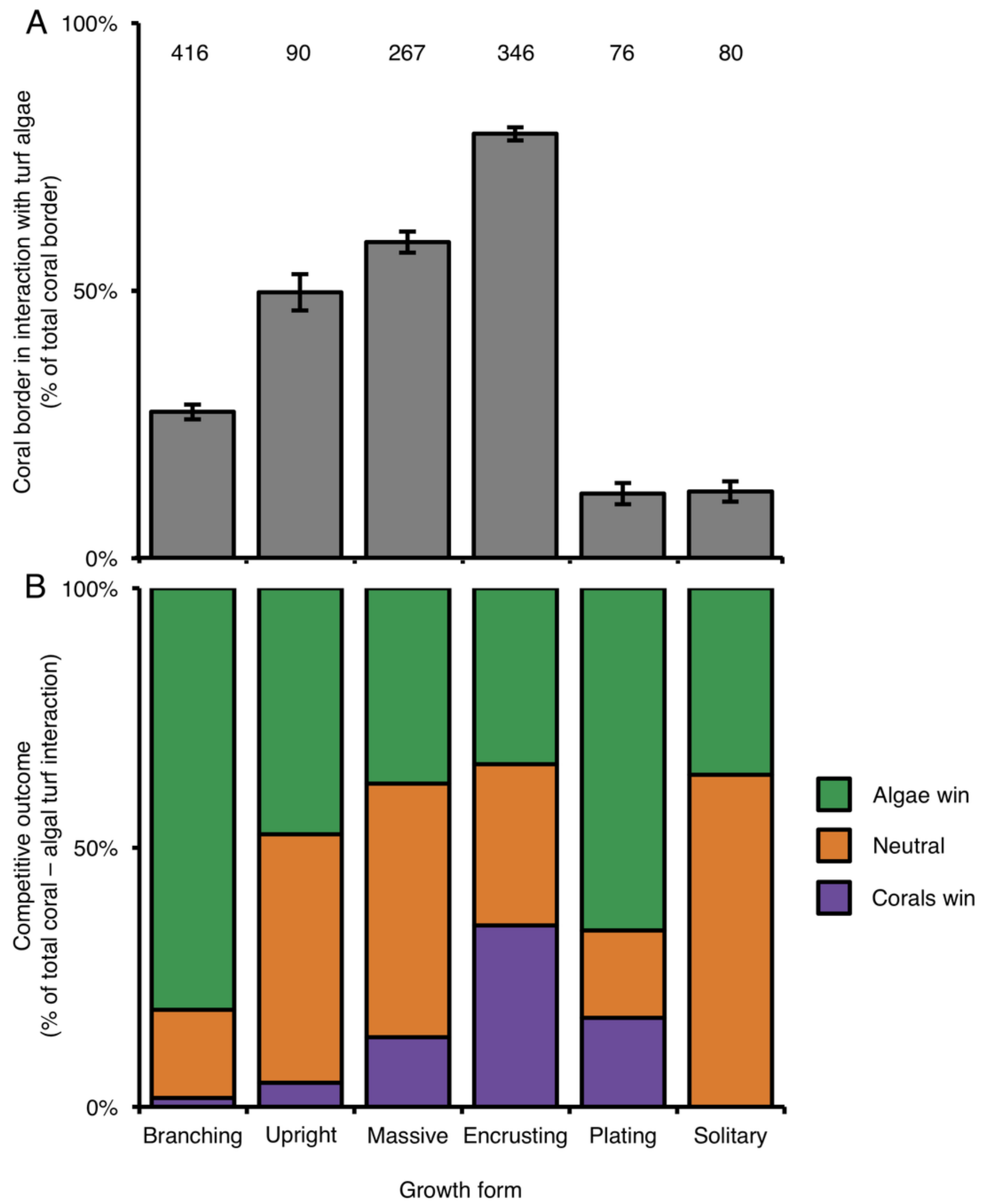


4

Directional competitive outcomes per coral colony growth form.

Values are calculated by 'corals winning directional competitive interactions / total directional competitive interactions'. Abbreviations: $\mathrm{B}=$ Branching, $\mathrm{U}=$ Upright, $\mathrm{M}=$ Massive, $\mathrm{E}=$ Encrusting, $\mathrm{P}=$ Plating, $\mathrm{S}=$ Solitary .

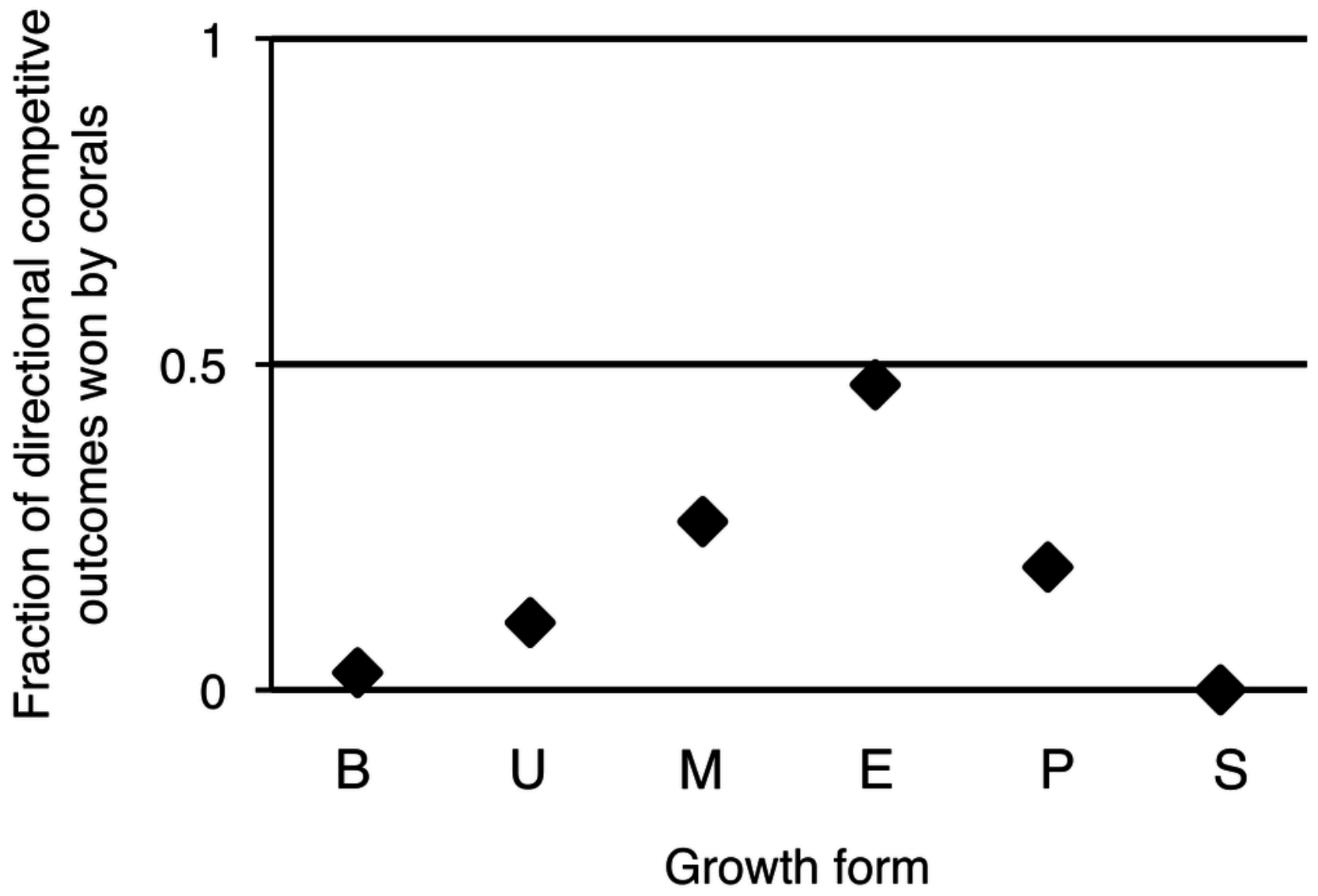




\section{5}

Competitive interactions between different coral genera and algae per coral colony growth form.

Top graphs (grey color) indicate the amount of coral colony border interacting with turf algae. Lower graphs (colored) indicate the competitive outcomes of coral-algal interactions. Numbers above bars indicate the amount of samples. Significance levels of different quantities of coral-algal competition along coral borders (in row under 'Border') and of different competitive outcomes (in row under 'Competitive outcome') between the compered growth forms are stated on the right of the charts. The ' $>$ ' means 'larger than'. P-values are indicated as $p<0.05=*, p<0.01=* *, p<0.001=* * *, p>0.05=$ n.s. (not significant). Abbreviations: $B=$ Branching, $E=$ Encrusting, $M=$ Massive, $P=$ Plating, $U=$ Upright. 

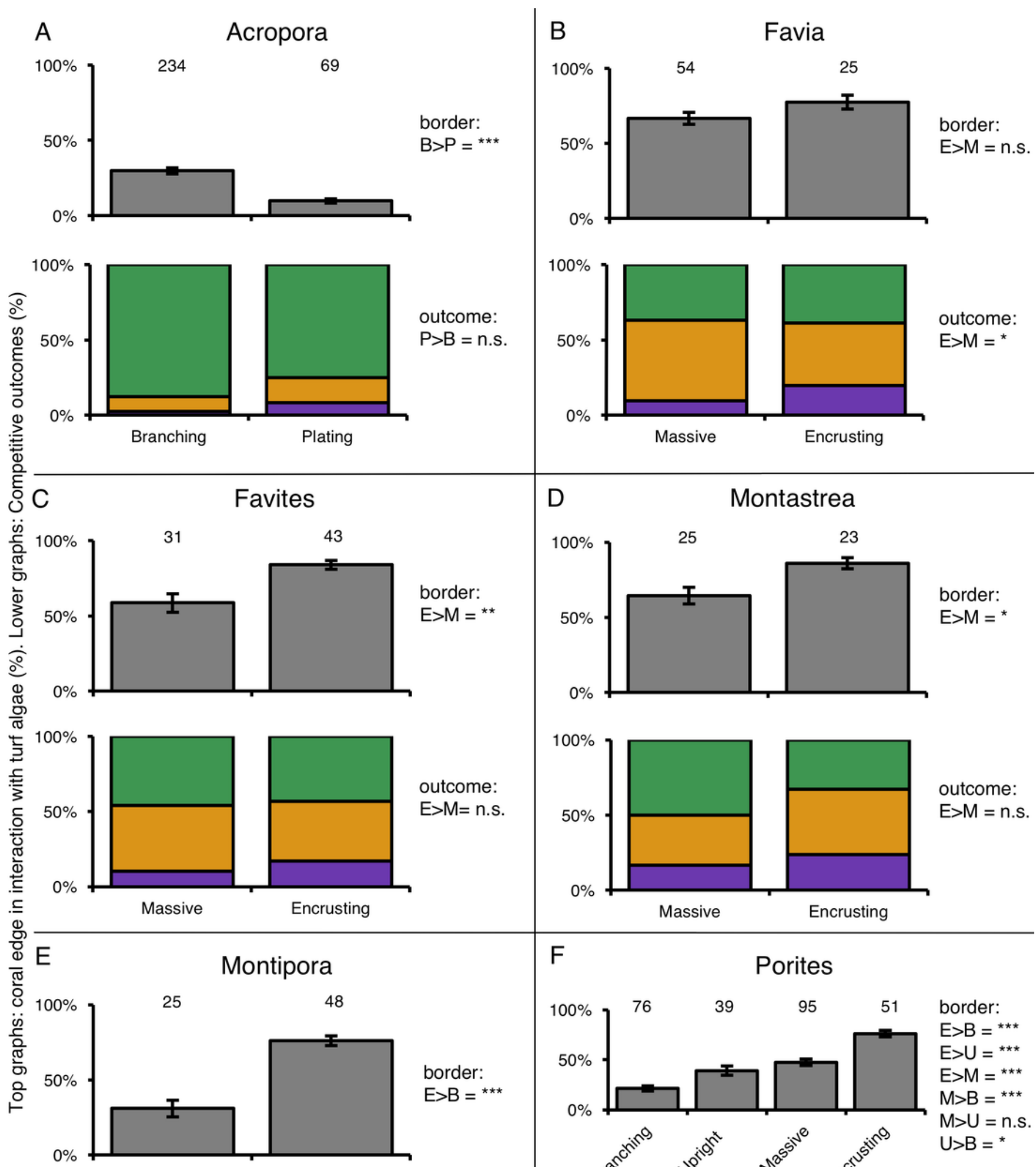

border:

$\mathrm{E}>\mathrm{M}=$ **

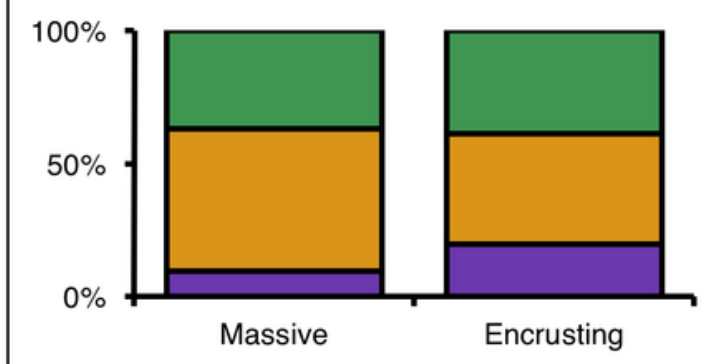

outcome:

$\mathrm{E}>\mathrm{M}=$ *
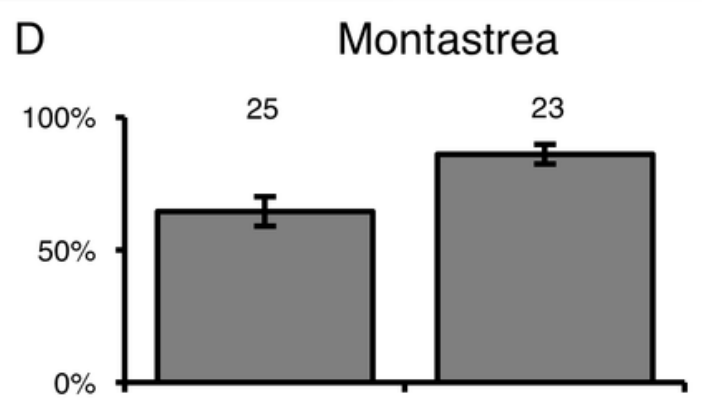

border:

$\mathrm{E}>\mathrm{M}=$ *
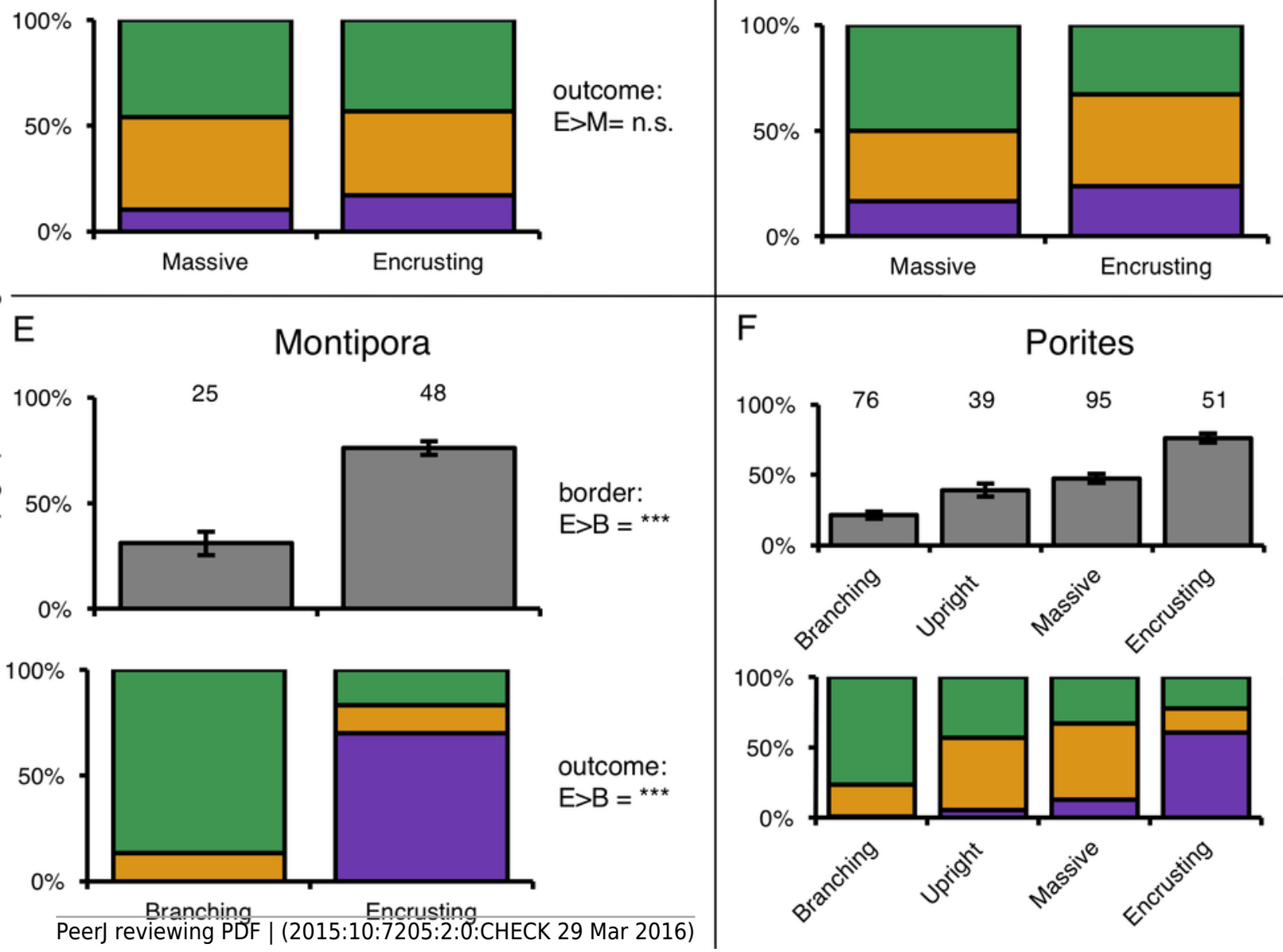

outcome:

$\mathrm{E}>\mathrm{M}=\mathrm{n}$.s.
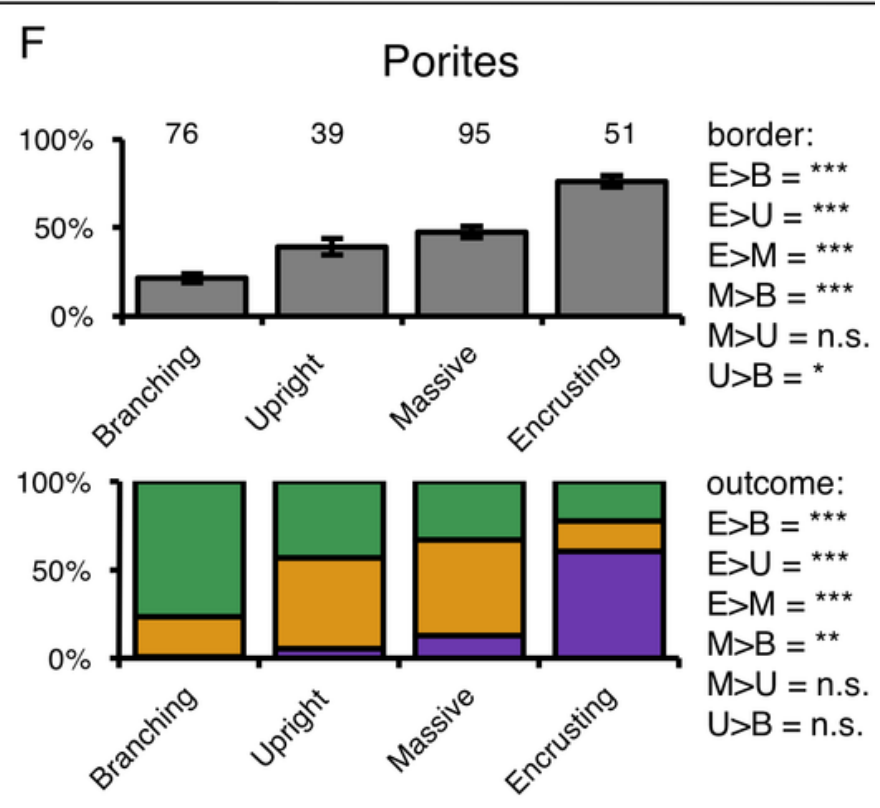
6

Coral - turf algal interactions per size class.

A: The amount of coral colony border interacting with turf algae per size class. B: The competitive outcomes of interactions between corals and turf algae per size class. Purple indicates the proportion won by corals, green the proportion won by algae and orange the proportion of neutral interactions. C: The directional competitive outcomes won by corals per size class. Numbers above graph A indicate the number of samples, numbers between brackets the number of corals involved in directional competitive interactions. 

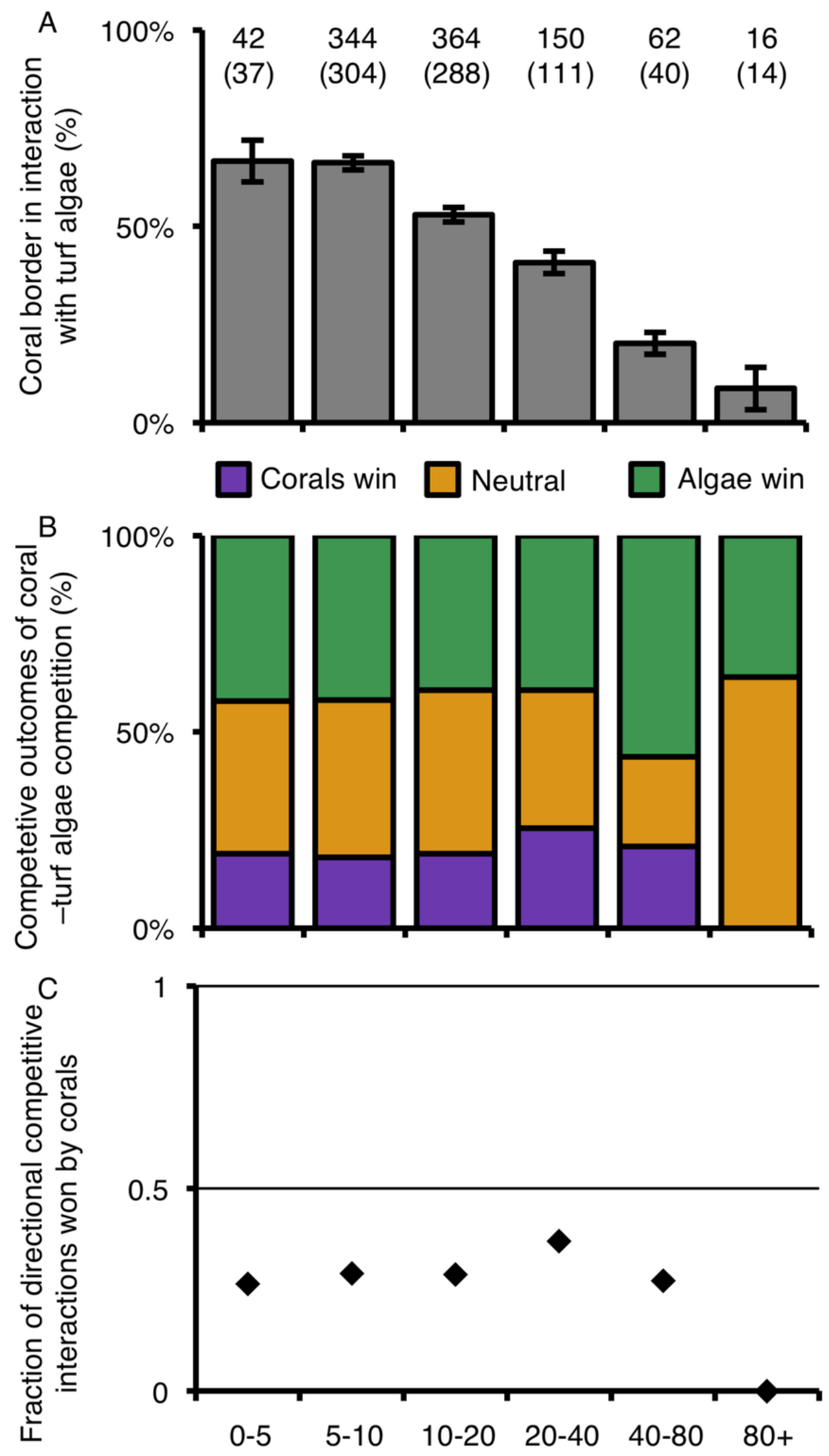


\section{Table $\mathbf{1}$ (on next page)}

Benthic cover and composition of the coral colony border.

Proportion of the total benthos and coral colony edge covered by or competing with different algal groups. p-values indicate significance levels of the disproportionality between the quantity of the functional group along the coral colony border compared to its coverage of the reef benthos based on a two-tailed binomial test: $*=<0.05 ; * *=<0.01 ; * * *=<0.001$. 
1

\begin{tabular}{|c|c|c|c|c|c|}
\hline & $\begin{array}{l}\text { coral border } \\
\text { interacting }(\mathrm{cm}) \text { of } \\
50538 \mathrm{~cm} \text { total } \\
\text { coral border }\end{array}$ & $\begin{array}{c}\text { coral border } \\
\text { interacting }(\%)\end{array}$ & $\begin{array}{l}\text { Average } \\
\text { interaction } \\
\text { along coral } \\
\text { edge per } \\
\text { colony (\%) }\end{array}$ & $\begin{array}{c}\text { Coverage of } \\
\text { reef benthos } \\
(\%)\end{array}$ & $\mathrm{p}$-Value \\
\hline $\begin{array}{l}\text { Brown } \\
\text { Algae }\end{array}$ & 1699 & 3.4 & 3.0 & 5.0 & $* * *$ \\
\hline $\begin{array}{l}\text { Green } \\
\text { Algae }\end{array}$ & 147 & 0.3 & 0.3 & 6.5 & $* * *$ \\
\hline Red Algae & 1136 & 2.2 & 2.6 & 0.4 & $* * *$ \\
\hline Turf Algae & 21066 & 41.7 & 42.8 & 34.9 & $* * *$ \\
\hline $\begin{array}{l}\text { Total with } \\
\text { algae }\end{array}$ & 24049 & 47.6 & 48.7 & 46.8 & \\
\hline
\end{tabular}

3

4

5

6 


\section{Table 2 (on next page)}

Pairwise comparisons between different coral colony growth forms with the KruskalWallis test.

Levels of significance of pairwise comparisons between coral colony growth forms for (I) different quantities of coral-algal competition along coral borders [in row under 'Border'] and (II) different competitive outcomes [in row under 'Competitive outcome']. The number of asterisks indicate the $p$-values after Bonferroni correction: $*=<0.05 ; * *=<0.01 ; * * *=$ $<0.001$, n.s. $=$ not significant. 
1

\begin{tabular}{|c|c|c|}
\hline Growth forms & Border & Competitive outcome \\
\hline Branching - Upright & $* * *$ & n.s. \\
\hline Branching - Massive & $* * *$ & $* * *$ \\
\hline Branching - Encrusting & $* * *$ & $* * *$ \\
\hline Branching - Plating & * & n.s. \\
\hline Branching - Solitary & n.s. & n.s. \\
\hline Upright - Massive & n.s. & n.s. \\
\hline Upright - Encrusting & $* * *$ & $* * *$ \\
\hline Upright - Plating & $* * *$ & n.s. \\
\hline Upright - Solitary & $* * *$ & n.s. \\
\hline Massive - Encrusting & $* * *$ & $* * *$ \\
\hline Massive - Plating & $* * *$ & n.s. \\
\hline Massive - Solitary & $* * *$ & ** \\
\hline Encrusting - Plating & $* * *$ & $* * *$ \\
\hline Encrusting - Solitary & $* * *$ & $* * *$ \\
\hline Plating - Solitary & n.s. & n.s. \\
\hline
\end{tabular}




\section{Table 3 (on next page)}

Pairwise comparisons between different coral colony size classes with the Kruskal-Wallis test.

Levels of significance of comparisons between size classes for (I) different quantities of coralalgal competition along coral borders [in column under 'Border'] and (II) different competitive outcomes [in column under 'Competitive outcome']. Size classes represent the maximum diameter of the coral colony in centimeter, and the size classes are separated with a '/' [in column under 'Size classes']. Asterisks indicate $\mathrm{p}$-values after Bonferroni correction: $*=$ $<0.05 ; * *=<0.01 ; * * *=<0.001$, n.S. $=$ not significant. 
1

\begin{tabular}{|c|c|c|}
\hline Size classes & Border & Competitive outcome \\
\hline $0-5 \mathrm{~cm} / 5-10 \mathrm{~cm}$ & n.s. & n.s. \\
\hline $0-5 \mathrm{~cm} / 10-20 \mathrm{~cm}$ & n.s. & n.s. \\
\hline $0-5 \mathrm{~cm} / 20-40 \mathrm{~cm}$ & * & n.s. \\
\hline $0-5 \mathrm{~cm} / 40-80 \mathrm{~cm}$ & $* * *$ & n.s. \\
\hline $0-5 \mathrm{~cm} / 80+\mathrm{cm}$ & *** & n.s. \\
\hline $5-10 \mathrm{~cm} / 10-20 \mathrm{~cm}$ & $* * *$ & n.s. \\
\hline $5-10 \mathrm{~cm} / 20-40 \mathrm{~cm}$ & $* * *$ & n.s. \\
\hline $5-10 \mathrm{~cm} / 40-80 \mathrm{~cm}$ & $* * *$ & n.s. \\
\hline $5-10 \mathrm{~cm} \mathrm{/} \mathrm{80+} \mathrm{cm}$ & $* * *$ & n.s. \\
\hline $10-20 \mathrm{~cm} / 20-40 \mathrm{~cm}$ & n.s. & n.s. \\
\hline $10-20 \mathrm{~cm} / 40-80 \mathrm{~cm}$ & *** & n.s. \\
\hline $10-20 \mathrm{~cm} \mathrm{/} 80+\mathrm{cm}$ & $* * *$ & n.s. \\
\hline $20-40 \mathrm{~cm} / 40-80 \mathrm{~cm}$ & n.s. & n.s. \\
\hline $20-40 \mathrm{~cm} / 80+\mathrm{cm}$ & n.s. & n.s. \\
\hline $40-80 \mathrm{~cm} / 80+\mathrm{cm}$ & n.s. & n.s. \\
\hline
\end{tabular}

